\title{
Starblanket, T. (2016). Suffer the Little Children: Genocide, Indigenous Nations and the Canadian State. Atlanta, GA: Clarity Press. 374 pp. USD 29.95, ISBN: 978-0998694771.
}

\section{Darryl Barthe ${ }^{1}$}

Ostensibly, Tamara Starblanket's Suffer the little children: Genocide, Indigenous nations and the Canadian state is a historical, criminological analysis of the Canadian Residential School system that was responsible for taking Indigenous children from their parents to disrupt cultural continuity and Indigenous identity formation. Overall, Starblanket's nearly 300 pages spanning monograph defends the proposition that Canada's Residential Schools were, in fact, weapons of genocide wielded purposefully by White Canadians against the people of Canada's First Nations.

The Residential School model existed in both Canada and the United States. It involved the systematic removal of Indigenous children - some as young as four - from their parents. These children were housed in crowded 'boarding schools' where - in addition to being subjected to an 'English only' education and corporal punishment for any expression of cultural heritage - they were "systematically demeaned and degraded, subjected to both physical and psychological torture (including wholesale sexual predation), denied $[. .$.$] adequate nutrition, medical care, or clothing, and typically$ impressed into manual labor" (p. 22). As Starblanket demonstrates, precisely and conclusively, this programme of organized, racist, colonial violence amounts to genocide, as the crime has been defined in international law.

Originally produced as a thesis for a Master of Laws, when laying out her foundational argumentative structure, Starblanket's work can seem overly defensive, constrained and rigid. While such meticulousness in constructing an argument is normal for academic work, one would expect a relaxation of tone in the publication of a monograph. After all, the

\footnotetext{
${ }^{1}$ Berkeley College Manhattan, NYC, US
} 
publication itself demonstrates the author's command of the material. With this said, it is easy to read her cautious, measured approach to this singularly horrific episode of White settler history in North America as preemptive, which is forgivable given the implications of Starblanket's argument, and the predictably contentious reception that it is likely to inspire from conservative historians and legal scholars. She knows very well that this work, which points accusing fingers at the settlers who rule Canada with the authority of a Master of Law, is going to meet resistance; she introduces her research by explaining the resistance she experienced from her colleagues.

I, the reviewer, am an Indigenous person from the United States and a historian with an abiding interest in the intersection of the history of race and criminology. From my vantage point, it seems self-evident that every book written by colonized people about their condition as colonized people should be read. In particular, it seems that the condition of colonized people in settler-states, who endure ongoing dispossession, should be of urgent interest, especially to those who benefit from that dispossession. For colonized people themselves - especially colonized people in academia reading about the experiences of other colonized people and of the experiences of colonized people in academia who choose to centre the narratives of their communities in their research, reading work like Starblanket's is almost therapeutic.

While her attention remains riveted on the intellectual and legal manoeuvrings of those embracing the interests of the Canadian settler-state, the arguments that Starblanket makes against genocide denial are no more exclusive to Canadians than settler-colonial violence is exclusive to Canadians. Reading her analysis of the "rubrics of denial" that White settlers engage in their approaches to the history of Indigenous erasure and "extirpation" in North America reminded me of a conversation I had with a Harvard-trained scholar of American Studies, originally from the American Midwest, who suggested to me that the United States' history with its Indigenous peoples could not be described as genocide because the word was only invented in the wake of World War II and, thus, could not be applied to previous episodes of comparable racist violence (it was that scholar who suggested the word extirpation to me as a preferable substitute). When Starblanket identifies White settler intellectuals' rhetorical squirming and obfuscation as part and parcel to the "barriers erected and maintained by [...] academic gatekeepers to prevent or at least limit the culpability"(p. 23) 
of the settler-state, she is talking specifically about Canada, but Canadians are not the only ones who engage in that sort of obfuscation. Again, Starblanket's work is almost therapeutic in this regard.

The substance of Starblanket's research itself, the actual acts of violence that she is characterizing as genocide, are as dark and horrible as one can imagine. In the choices that she makes, to offer the evidence that she does, in the way that she offers that evidence, she issues a challenge to those who would dismiss or minimize her claim. She demands that her reader recognizes the Residential School System as an instrument of genocide, but such an admission seems almost inconsequential when one considers that entire generations of children were destroyed or rendered disabled through trauma as a result of the most vicious racist brutality and torture imaginable. Tamara Starblanket's account is unrelenting. Her work is a testimony, a chronicle; she is bearing witness.

The second chapter of her book is short-titled as "The Horror." In it, she offers details into the culture of the Residential School system, which was often administered by religious faculty, including priests and nuns. She describes children who were forced to eat their own vomit and who were routinely denied medical care (p. 116). She describes punishments that included intentionally burning children or scalding them with hot water; she describes beatings that resulted in permanent or semi-permanent injury; she describes children having their arms, ribs and skulls broken (p. 117). She describes organized programmes of sexual violence including child-rape, and the inducing of abortions in children impregnated by male administrative staff (p. 125). Crucially, Starblanket connects this history of violence to contemporary realities of Indigenous child removal in the Canadian child welfare system.

Given the horrific scenes of genocidal violence unfolding at the concentration camps at the US Mexican border, the timeliness of Starblanket's work is undeniable. As a White nationalist settler-government separates Indigenous children from their parents, denying them access to education, medical care and meaningful legal representation, it is clear that Starblanket's work and the history that she is recounting is perhaps more relevant than ever. 
